\title{
The Correlation between Diet and The Type of Cancer at The Chemotherapy Rooms in General Hospital Abdul Wahab Sjahranie Samarinda
}

\author{
Rini Ernawati ${ }^{1 *}$, Niswatun Amanah ${ }^{2}$, \\ ${ }^{1}$ Departement of Nursing, Faculty of Health andPharmacy, Universitas \\ Muhammadiyah Kalimantan Timur, Indonesia \\ ${ }^{2}$ Departement of Nursing, Faculty of Health and Pharmacy, \\ UniversitasMuhammadiyah Kalimantan Timur, Indonesia
}

*E-mail : re840@umkt.ac.id

\begin{abstract}
Cancer is an abnormality in the body organs, for instance the abnormal cells grow very quickly, and consequentlydisrupt the performance of normal cells. An unhealthy meal pattern can cause cancer and stress and in long term it can cause thedecrease of immunity, as the result someone with low immunity is at risk to get sick easily.The purpose of the research was toidentify the correlation between diet and the type of cancer at the chemotherapy rooms in General Hospital Abdul Wahab Sjahranie.This study employed quantitative research design with cross sectional approach. The number of the population in this research was 183 respondents and 125 samples were selected to participate with purposive random sampling technique. The instruments of meal pattern questionnaire is used to collect the data and Chi-Square test was utilized to analyse the statistics test.The finding from the correlation between the variable of meal pattern and the type of cancer showed significant result pvalue $=0.003 a<0.05$. This means that there was significant correlation between diet and the type of cancer. This result indicate that is significant influence between meal pattern with the type of cancer
\end{abstract}

Keywords: Diet, type of cancer 


\section{INTRODUCTION}

Cancer is the second leading cause of death worldwide. In 2018 there were around 9.6 million deaths due to cancer. Globally, about 1 in 6 deaths is due to cancer. About $70 \%$ of cancer deaths occur in low and middle income countries.According to data from The GLOBOCAN 2018 global cancer is estimated to increase to 18.1 million new cases and 9.6 million deaths by 2018 . 1 in 5 men and 1 in 6 women worldwide suffer from cancer during their lifetime, and 1 in 8 men and 1 in 11 women die from cancer. Around the world, in an estimated 5 years there were 43,800,000 people diagnosed with cancer. The increase in cancer cases is due to several factors, including population growth and aging as well as the prevalence of certain cancer-causing changes related to social and economic development.

The incidence of cancer patients in the population of all ages in Indonesia is $1.4 \%$ with the highest incidence of cancer in the Province of DI Yogyakarta, which is $4.1 \%$, far higher than the national rate. In Indonesia, cervical and breast cancer are cancer with the highest incidence in Indonesia in 2013, namely cervical cancer $0.8 \%$ and breast cancer $0.5 \%$. East Kalimantan Province ranks seventh at $1.7 \%$. The incidence of cancer in East Kalimantan for cervical cancer $0.4 \%$ diagnosis by doctors with an estimated number of 752 patients, breast cancer $1.0 \%$ diagnosed by doctors with an estimated number of 1,879 patients, colon cancer and rectum $1.2 \%$ diagnosed by doctors with an estimated amount as many as 1,923 patients, lung cancer $0.8 \%$ with an estimated total of 875 patients, blood cancer $0.3 \%$ with an estimated total of 653 patients.

Data of cancer patients in the hospital. Abdul Wahab Sjahranie for rectal cancer for 88 patients, breast cancer for 528 patients, lung cancer for 228 patients, blood cancer / leukemia for 248 patients, and cervical cancer for 329 patients with a total of 1421 cancer patients. According to the National Cancer Institute and the American Cancer Society the cause of cancer is not known with certainty, there are several risk factors that can cause cancer ${ }^{1}$. One of them is eating patterns. Patterns of food affect the ability to digest growth substances or nutrients in food that are eaten do not run alone and are interdependent between these substances. Food intake can have a bad or good effect on the growth of cancer cells ${ }^{2}$.

\section{MATERIAL AND METHOD}

The sudy used a descriptive quantitative cross sectional design. The population in this study was 183 respondents with a sample of 125 cancer patients treated in the chemotherapy room Abdul Wahab Sjahranie Hospital. How to take samples using purposive random sampling. Patients who did not meet the study requirements were excluded. Data taken using a questionnaire. The study was conducted after obtaining permission from the patient. The process of data analysis consists of editing, coding, data entry, tabulation and cleaning. Data analysis uses the chi square test 


\section{RESULT AND DISCUSSION}

Table 1

Meal paterrn of patients

\begin{tabular}{|c|c|c|c|}
\hline No & Meal paters & Freluency & (\%) \\
\hline 1 & No healthy & 68 & $54.4 \%$ \\
\hline 2 & health & 57 & $45.6 \%$ \\
\hline & Amount & 125 & $100 \%$ \\
\hline
\end{tabular}

Based on result of study obtained data for unhealthy diet as many as 68 respondents( 4,4 $\%)$ and healthty diet 57 respondents ( 45,6\%)

Tabel 2

Type of cancer patients

\begin{tabular}{|c|c|c|c|}
\hline \multicolumn{3}{|c|}{ Type of cancer pationts } \\
\hline No & Type of cancer & Frckucucy & (\%) \\
\hline 1 & Breast cancer & 39 & $31.2 \%$ \\
\hline 3 & Colon'Rektum cancer & 35 & $28.0 \%$ \\
\hline 4 & Serviks cancer & 29 & $23.2 \%$ \\
\hline & Lungs cancer & 22 & $17.6 \%$ \\
\hline & Amount & 125 & $100 \%$ \\
\hline
\end{tabular}

Based on the results of the study found that the types of cancer experienced by respondents were breast cancer as many as 39 people (31.2\%), colon / rectal cancer 35 people $(28.0 \%)$, cervical cancer 29 people (23.2\%), and lung cancer 22 people ( $17.6 \%)$.

Table 3

Analysis between meal patercr and cancer type of patients

\begin{tabular}{|c|c|}
\hline Variabel & P-Vahue \\
\hline Meal patern and cancer type & 0.003 \\
\hline
\end{tabular}


Based on the results of statistical tests with chi square obtained p value $=0.003(<0.05)$, it can be concluded that there is a relationship between diet and the type of cancer in the chemotherapy room Abdul Wahab Sahranie Hospital Samarinda

\section{Univariate}

Based on the results of the study showed that more unhealthy eating patterns as many as 68 people $(54.4 \%)$. A person's diet can have a positive or negative impact on a person and the ability to digest growth substances or nutrients in food that is eaten does not work alone but are interdependent between these substances. Food intake can have a bad or good effect on the growth of cancer cells ${ }^{2}$. Pattern. Eating patterns can also be called eating habits. A good diet is to consume foods that are sourced from vegetables, fruit. Fish. Unhealthy eating patterns include fatty foods, sweet foods, fermented foods, alcohol and the like.

An example is french fries, for Westerners potatoes have become a staple food and usually potatoes are fried. Like fried potatoes that are ready to serve you just fry it and continue eating right away, forming acrylimde. Acrylimde can cause various cancers such as uterine cancer, lung cancer lung, kidney cancer, throat cancer, etc.

Excessive consumption of fat can increase the risk of cancer. This is because fat is Cancer Promoting. The presence of fat in the body makes carcinogenic substances, substances that form the development of cancer. Some of the ways fat nutrients support cancer, namely: as a cause for the body to secrete certain hormones in excess, including excessive secretion of the hormone estrogen. Increasing the concentration of estrogen in the blood increases the risk of developing breast cancer because of the proliferation effect of estrogen on the ductus of the breast ephithelium and as a cause of secretion of excess bile into the intestine which is subsequently by microorganisms in the colon converted into carcinogenic substances.

Based on the results of the study, researchers assumed that the people of Samarinda in consuming food contained less fiber and they were in food processing especially fish and chicken protein by frying and burning, so that data obtained that the majority of respondents' eating patterns were unhealthy. Researchers suggest that people consume more fruits and vegetables, as well as process food by cooking it using water (boiling), so that the eating patterns of samarinda city people are healthier, and can prevent various diseases, one of which is cancer. 


\section{Bivariate}

\section{Relationship between diet and type of cancer}

The results of the analysis of the relationship between eating patterns with cancer using statistical tests with chi square obtained $\mathrm{p}$ value $=0.003(<0.05)$, it can be concluded that there is a relationship between eating patterns with cancer types in the chemotherapy room Abdul Wahab Sahranie Hospital Samarinda. These results are consistent with what was done with a result of $\mathrm{p}=0.01(<0.05)$ which means there is a relationship between diet and cancer incidence at the Hospital and Oncology Clinic in Banda Aceh ${ }^{3}$.

Seeing this, researchers assume that there is a relationship between eating patterns with the incidence of cancer in the chemotherapy room Abdul Wahab Sjahranie Hospital Samarinda. Where the diet is closely related to the incidence of cancer. From that seen during research in patients in the chemotherapy room Abdul Wahab Sjahranie Hospital Samarinda where most respondents or patients in the chemotherapy room who suffer from cancer many who come from villages or areas far from urban areas so, lack of access to health services. Need to do a health check so that diseases can be detected more quickly and health education can be given in order to prevent cancer through improving healthier eating patterns

\section{CONCLUSION}

From the results of the study of the relationship between eating patterns and types of cancer in the chemotherapy room Abdul Wahab Sjahranie Hospital Samarinda it was concluded that the age of respondents at most was $46-55$ years as many as 44 people (35.2\%), there was a significant relationship between eating patterns and types of cancer in the chemotherapy room Abdul Wahab Sjahranie Hospital in Samarinda, with the chi square test obtained $\mathrm{p}$ value $=0.003(<0.05)$.

\section{REFERENCES}

1. American Cancer Soceity.2.Breast Cancer, What Are the Risk Factors For Breast cancer (2016).

2. Ruiz, B. R., \& Hernandez, P. S. 2013.Diet dan Cancer: Risk Factor and Epidemiologi Evidence. (2013)

3. Eva, Fitriyaningsih, Hubungan Pola Makan Dengan Resiko Kanker Payudara(Studi Kasus Pada Rumah Sakit dan Klinik Onkologi di Banda Aceh). TerbitanJurnal. Banda Aceh (2014) 